\title{
AUDIT PEMASARAN DI BADAN USAHA MILIK DESA "X" KABUPATEN KARANGANYAR
}

\author{
Hanafi Adi Putranto \\ UIN Sunan Ampel Surabaya \\ hanafiadiputranto@uinsby.ac.id \\ Hastanti Agustin Rahayu \\ UIN Sunan Ampel Surabaya \\ hastanti.rahayu@uinsby.ac.id
}

\begin{abstract}
Tujuan dari penelitian ini untuk mengetahui strategi dari hasil audit pemasaran Badan Usaha Milik Desa "X"melalui perbandingan Competitive Setting Profil dengan Company Alignment Profil. Metode penelitian yang digunakan dengan pendekatan kuantitatif menggunakan audit strategi marketing plus dengan melakukan perbandingan nilai Company Alignment Index (CAI) dan Competitive Setting Index (CSI). Hasil perbandingan CSI lebih besar dari CAI menjelaskan bahwa Badan Usaha Milik Desa " $X$ " tetap dan fokus untuk lingkup Marketing Oriented dengan langkah; 1. Market Effective, dalam hal ini BUMDes mempunyai strategi yang efektif guna mencapai tujuannya. Perlu diperhatikan juga dalam optimalisasi penjualan pemasarannya. Jika produk dan jasa yang dimiliki BUMDes lebih fokus dan efektif sasarannya kepada konsumen di lingkup BUMDes tersebut. Dalam hal ini masyarakat desa setempat sebagai sasaran pasarnya. 2. Product Differentiation, adanya pembeda dalam produk atau jasa yang dimiliki BUMDes dengan lainnya. Hal ini diperlukan untuk memperoleh perhatian dari konsumen terkait dari manfaat, desain, harga, kualitas, pelayanan produk atau jasa BUMDes tersebut. 3. Balanced Promotion, diperhatikan bahwa dalam aktivitas promosi juga membutuhkan keseimbangan biaya. Kegiatan promosi produk dan jasa BUMDes yang tinggi memerlukan biaya yang tinggi. Sehingga dibutuhkan aktivitas promosi yang efektif namun juga tepat sasaran ke konsumen.
\end{abstract}

Keywords: Audit pemasaran; Competitive Setting Profil; Company Alignment Profil; Strategic Marketing Plus 2000

\section{PENDAHULUAN}

Tujuan dari Program Nawacita yakni membangun Indonesia dengan memperkuat daerah dan desa, dengan harapan pembangunan nasional secara merata dapat dirasakan masyarakat. Undang-Undang Nomor 6 Tahun 2014 tentang Desa merupakan dasar hukum dari kebijakan Dana Desa yang bersumber dari Anggaran Pendapatan dan Belanja Negara (APBN). Penerimaan Dana Desa dari tahun ke tahun mengalami peningkatan (lihat tabel 1). Pemanfaatan dana desa ditujukan untuk pembangunan dan pemberdayaan masyarakat. Salah satu Output dari pemberdayaan masyarakat adalah pendirian Badan Usaha Milik Desa (BUMDes). Tujuan penyaluran dana desa terutama terkait dalam peningkatan pelayanan publik 
di desa, pengentasan kemiskinan, memajukan perekonomian desa, serta mengurangi kesenjangan pembangunan antar desa dan memperkuat masyarakat desa sebagai subyek dari pembangunan.

Tabel 1. Dana Desa Tahun 2015 - 2019

\begin{tabular}{|l|r|r|r|r|r|}
\hline \multicolumn{1}{|c|}{ Uraian } & \multicolumn{1}{|c|}{$\begin{array}{c}\text { APBN } \\
2015\end{array}$} & \multicolumn{1}{c|}{$\begin{array}{c}\text { APBN } \\
2016\end{array}$} & \multicolumn{1}{c|}{2017} & \multicolumn{1}{c|}{2018} \\
\hline $\begin{array}{l}\text { Transfer ke } \\
\text { Daerah }\end{array}$ & $637.975,1$ & $723.191,2$ & $811.843,7$ & $1.037 .911,6$ & $1.118 .401,7$ \\
\hline$\%$ Dana Desa & $1,42 \%$ & $6,40 \%$ & $10,00 \%$ & $10,00 \%$ & $10,00 \%$ \\
\hline $\begin{array}{l}\text { Dana Desa } \\
\text { (miliar) }\end{array}$ & $9.066,2$ & $46.982,1$ & $81.184,3$ & $103.791,1$ & $111.840,2$ \\
\hline $\begin{array}{l}\text { Rata-rata per } \\
\text { desa (juta) }\end{array}$ & 122,4 & 628,5 & $1.095,7$ & $1.400,8$ & $1.509,5$ \\
\hline $\begin{array}{l}\text { Alokasi Dana } \\
\text { Desa ADD } \\
\text { (miliar) Hasil }\end{array}$ & $33.430,8$ & $36.723,9$ & $42.285,9$ & $55.939,8$ & $60.278,0$ \\
\hline $\begin{array}{l}\text { Bagi } \\
\text { PDRB (miliar) }\end{array}$ & $44.589,0$ & $86.356,4$ & $126.204,2$ & $162.786,3$ & $175.494,9$ \\
\hline $\begin{array}{l}\text { Total } \\
\text { (DD+ADD+BH } \\
\text { PDRB) }\end{array}$ & & $2.650,4$ & $2.733,8$ & $3.055,3$ & $3.376,7$ \\
\hline $\begin{array}{l}\text { Rata-rata per } \\
\text { desa (juta) }\end{array}$ & 601,8 & $1.115,2$ & $1.703,3$ & $2.197,1$ & $2.368,6$ \\
\hline
\end{tabular}

Sumber : data diolah dari APBN

Kementerian Desa, Pembangunan Daerah Tertinggal dan Transmigrasi (Kemendes PDTT) memiliki empat program prioritas antara lain pengembangan Produk Unggulan Kawasan Perdesaan (Prukades), pembentukan Badan Usaha Milik Desa (BUMDes), pembangunan Embung Desa dan pembangunan Sarana Olah raga Desa. Kajian dari Badan Kebijakan Fiskal dan Politeknik Keuangan Negara STAN terhadap seribu desa di Indonesia menyatakan bahwa Dana Desa meningkatkan secara positif keberadaan Badan Usaha Milik Desa (BUMDes), kesempatan kerja dan persepsi masyarakat tentang infrastruktur.

Hasil audit BPK menyatakan bahwa penggunaan dana desa terkait Badan Usaha Milik Desa (BUMDes) belum memberikan kontribusi terhadap peningkatan perekonomian desa. Sehingga berdasarkan uji petik terhadap 8.220 Badan Usaha Milik Desa (BUMDes) menunjukkan bahwa 27\% Badan Usaha Milik Desa (BUMDes) yang didirikan tidak beroperasi dan 20\% Badan Usaha Milik Desa (BUMDes) belum berkontribusi pada pendapatan desa. Hasil dari uji petik lainnya 1.034 Badan Usaha Milik Desa (BUMDes) belum menyampaikan laporan dan 871 Badan Usaha Milik Desa (BUMDes) pembentukannya belum melalui studi 
kelayakan, dan 864 Badan Usaha Milik Desa (BUMDes) belum tertib dalam pelaporan Badan Usaha Milik Desa (BUMDes). Selanjutnya dari 585 Badan Usaha Milik Desa (BUMDes) belum didukung dengan kemampuan pengelola yang kompeten. Dan dari 547 Badan Usaha Milik Desa (BUMDes) jenis usaha belum sesuai dengan potensi unggulan desa. Peraturan Menteri Desa (Permendesa) Nomor 4 Tahun 2015 tentang Badan Usaha Milik Desa (BUMDes), belum spesifik peraturan mengenai pengawasan Badan Usaha Milik Desa (Badan Usaha Milik Desa (BUMDes) oleh pihak eksternal.

Begitu pula dengan produk dan jasa yang ada di Badan Usaha Milik Desa (BUMDes), alat ukur untuk menilai, mengawasi sejauhmana Badan Usaha Milik Desa (BUMDes) tersebut dikatakan efektif dan efisien juga belum optimal. Dalam rencana pemasaran berfungsi sebagai pengarah untuk mengambil keputusan operasional. Sehingga diperlukan audit pemasaran untuk meninjau sistematis yang ada dalam strategi dan rencana pemasaran yang akan dilaksanakan. Dalam pelaksanaannya audit pemasaran dapat dilaksanakan baik secara intenal maupun eksternal terkait strategi pemasaran, sistem pemasaran, organisasi pemasaran, identifikasi ingkungan, maupun pihak stakeholdernya.

Audit pemasaran dalam lingkup BUMDes diperuntukkan dalam mendapatkan manfaat, investigasi, serta pertimbangan aktifitas pemasaran di BUMDes sehingga nantinya saat implementasi kebijakan dan strategi pemasarannya tepat sasaran dalam masa yang akan datang.

Tabel 2. The Strategic Marketing Plus 2000 Conceptual Framework

\begin{tabular}{|c|c|c|c|c|c|}
\hline Nilai & 1 & 2 & 3 & 4 & 5 \\
\hline $\begin{array}{l}\text { Compa } \\
\text { ny }\end{array}$ & Producer & Seller & Marketer & Specialist & $\begin{array}{l}\text { Service } \\
\text { Provider }\end{array}$ \\
\hline $\begin{array}{l}\text { Type of } \\
\text { Compa } \\
\text { ny }\end{array}$ & $\begin{array}{l}\text { Production } \\
\text { Oriented }\end{array}$ & $\begin{array}{l}\text { Selling } \\
\text { Oriented }\end{array}$ & $\begin{array}{l}\text { Marketing } \\
\text { Oriented }\end{array}$ & $\begin{array}{l}\text { Market } \\
\text { Driven }\end{array}$ & $\begin{array}{l}\text { Customer } \\
\text { Driven }\end{array}$ \\
\hline $\begin{array}{l}\text { Key } \\
\text { Succesf } \\
\text { ul } \\
\text { Factor }\end{array}$ & $\begin{array}{ll}\text { - } & \text { Operatio } \\
\mathrm{n} \\
\text { Efficienc } \\
\mathrm{y} \\
\text { - } & \text { Product } \\
\text { Standard } \\
\text { ization } \\
\text { - Mass } \\
\text { Distribut } \\
\text { ion }\end{array}$ & $\begin{array}{ll}\text { - } & \text { Persuasi } \\
\text { ve } \\
\text { selling } \\
\text { - } & \text { Product } \\
\text { featurin } \\
\mathrm{g} \\
\text { - Mass } \\
\text { promoti } \\
\text { on }\end{array}$ & $\begin{array}{ll}\text { - } & \begin{array}{l}\text { Market } \\
\text { effectiv }\end{array} \\
\mathrm{e} \\
\text { - } & \text { Product } \\
\text { differen } \\
\text { tiation } \\
\text { - } \text { Balance } \\
\text { promoti } \\
\text { on }\end{array}$ & $\begin{array}{ll}\text { - } & \text { Niche } \\
\text { selectivit } \\
\text { y } \\
\text { - } \quad \text { Product } \\
\text { specializ } \\
\text { ation } \\
\text { - Integrate } \\
\mathrm{d} \\
\text { commun } \\
\text { ication }\end{array}$ & $\begin{array}{l}\text { - } \begin{array}{l}\text { Data } \\
\text { base }\end{array} \\
\text { accounta } \\
\text { bility } \\
\text { - } \\
\text { Product } \\
\text { costomiz } \\
\text { ation } \\
\text { - Interacti } \\
\text { ve } \\
\text { commun } \\
\text { ication }\end{array}$ \\
\hline
\end{tabular}

Sumber : Hermawan Kertajaya, 1999 


\section{KAJIAN PUSTAKA}

Penelitian mengenai audit pemasaran oleh Erita dan Asmai (2005) dengan metode Competitive Audit berdasarkan Strategic Marketing Plus 2000 bahwa dari hasil analisis audit pemasaran sebagai acuan perusahaan untuk memodifikasi strategi serta taktik pemasarannya dalam meningkatkan nilai perusahaan dan mampu beradaptasi dengan lingkungan bisnisnya.

\section{Badan Usaha Milik Desa}

Badan Usaha Milik Desa (BUMDes) dalam Permendagri No. 39 Tahun 2010 merupakan bentuk usaha desa yang didirikan oleh pemerintah desa dan dalam modal serta pengelolaannya dilaksanakan pemerintah desa dan masyarakat dengan tujuan memperkuat perekonomian desa berdasarkan kebutuhan dan potensi desa. Dilihat dari peraturan tersebut maka berdirinya Badan Usaha Milik Desa (BUMDes) berdasarkan kebutuhan, potensi, kapasitas desa, dan tentunya untuk peningkatan kesejahteraan masyarakat.

\section{Strategi Pemasaran}

Strategi pemasaran menurut (Kotler and Amstrong, 2012) adalah logika pemasaran dimana perusahaan berharap dapat menciptakan nilai bagi customer dan dapat mencapai hubungan yang menguntungkan dengan pelanggan. Menurut American Marketing Association 2007 pemasaran adalah aktivitas, serangkaian institusi dan proses menciptakan, mengkomunikasikan, menyampaikan, dan mempertukarkan tawaran yang bernilai bagi pelanggan, klien, mitra, dan masyarakat umum (Tjiptono dan Chandra, 2012).

\section{Pemasaran dalam Sektor Publik}

Serrat \& Serrat (2017) mengemukakan saat pemasaran sebagai wacana di lingkup sektor publik serta telah disepakati dan tujuan, kondisi, dan tugasnya yang khas dihargai, kemudian pemasaran sebagai seperangkat ide terintegrasi dapat digunakan. Ini tidak berarti bahwa kekuatan tradisional pegawai negeri dari ekuitas, akuntabilitas, ketidakberpihakan, dan tinjauan luas dari kepentingan publik dengan demikian ditinggalkan. Tentu saja, sektor publik telah lama memiliki elemen pemasaran tetapi mereka biasanya terpinggirkan dalam penyediaan barang dan jasa publik inti. Sehingga pendekatan pemasaran hanya memerlukan sedikit manfaat selain penggunaan alat khusus, bukan pengembangan dan adopsi orientasi pemasaran.

\section{Audit Pemasaran}

Taghian dan Shaw (2008) mengemukakan audit pemasaran sebagai fasilitas yang dapat membantu pembentukan, pemeliharaan, dan manajemen dari strategi orientasi 
pasar sehingga dalam praktik audit pemasaran dan manfaat yang dirasakannya diperiksa, dan hubungannya dengan perubahan kinerja bisnis. Audit pemasaran telah didefinisikan sebagai pemeriksaan yang komprehensif, sistematis, independen, dan berkala terhadap lingkungan pemasaran perusahaan atau unit bisnis, tujuan, strategi, dan aktivitas dengan tujuan untuk menentukan area masalah dan peluang serta merekomendasikan sebuah rencana. tindakan untuk meningkatkan kinerja pemasaran perusahaan (Kotler, Gregor, dan Rodgers, 1977).

Konsep Marketing Plus 2000

Kartajaya (1995) menilai audit pemasaran dapat dilakukan dengan menggunakan metode audit pemasaran berdasarkan strategi marketing plus. Faktor-faktor yang dinilai dalam audit pemasaran berdasarkan strategi marketing plus meliputi 4C yang terdiri dari Customer (C1), Company (C2), Competitor (C3) dan Change Driver (C4). Penggunaan tiga faktor pertama yaitu costumer, company, dan competitor sangat umum digunakan dalam penyusunan strategi dan taktik pemasaran. Selanjutnya karena kini di berbagai negara menunjukkan tingkat turbelensi dari lingkungan bisnis semakin tinggi, maka faktor change/perubahan tidak bisa lagi ditinggalkan.

\section{METODE PENELITIAN}

Metode penelitian yang digunakan adalah metode studi kasus dengan pendekatan kuantitatif, populasi dalam penelitian ini adalah 30 pengurus dan anggota BUMDes yang menjadi sampel. Sugiyono (2014) populasi merupakan wilayah generalisasi yang terdiri atas obyek/subyek yang mempunyai kualitas dan karakteristik tertentu yang ditetapkan oleh peneliti untuk dipelajari dan kemudian ditarik kesimpulannya. Metode pengambilan sampel yang digunakan adalah model Convenience Sampling yaitu suatu metode yang menarik anggota populasi tertentu saja. Convenience Sampling merupakan metode yang reliabel dan merupakan cara yang murah dan mudah untuk dilakukan (Cooper \& Schnidler, 2006).

Untuk menganalisis keunggulan kompetitif strategi pemasaran suatu perusahaan dapat digunakan metode audit strategi marketing plus (Hendri, 2000; Komaruddin, 2002; Mandra, 2002; Rangkuti, 2002; Ritonga, 2015) yang merupakan suatu metode analisis deskriptif kuantitatif. Metode audit strategi marketing plus menggunakan teknik perbandingan antara Competitive Setting Index dengan Company Alignment Index yang diukur menggunakan skala penilaian yang keduanya diperoleh berdasarkan tingkat keyakinan responden sebagai berikut :

1. Saat sebaran form sudah siap dan diisi kemudian tahapan berikutnya dengan menghitung nilai rata-rata dari setiap profil yang didapat dari semua responden. Kemudian tahapan selanjutnya menghitung per responden secara keseluruhan. Selanjutnya dari hasil tersebut disebut dnegan Competitive Setting Index dimana 
index yang diperoleh dari hasil rata-rata Competitive Setting Profil, serta Company Alignment Index diperoleh dari hasil rata-rata Company Alignment Profil.

2. Membandingkan hasil keseluruhan dari Competitive Setting Index dengan Company Alignment Profil :

a. Jika CAI > CSI maka hasilnya Positif.

b. Jika CAI < CSI maka hasilnya Negatif.

\section{HASIL DAN PEMBAHASAN}

Tabel 3. Competitive audit CSI score rata-rata dan standar deviasi

\begin{tabular}{lcc}
\hline \multicolumn{1}{c}{ Dimensi } & Score Rata-Rata & Standar Deviasi \\
\hline Enlightened & 3,9 & 0,8 \\
Informationalized & 3,9 & 0,9 \\
Empowered & 4,0 & 0,8 \\
General & 4,0 & 0,8 \\
Aggressiveness & 4,0 & 0,8 \\
Capability & 4,0 & 0,8 \\
Economic & 3,9 & 0,8 \\
Technology & 3,9 & 0,8 \\
Social & 3,9 & 0,8 \\
Competitive Setting Index & 4,0 & \\
\hline
\end{tabular}

Sumber : Data Sekunder diolah, 2020 (SPSS V 20).

Tabel 4. Competitive audit CAI

\begin{tabular}{lcc}
\hline \multicolumn{1}{c}{ Dimensi } & Score Rata-Rata & Standar Deviasi \\
\hline Segmentation & 3,5 & 0,8 \\
Targeting & 3,9 & 0,6 \\
Positioning & 3,6 & 0,5 \\
Differentiation & 3,2 & 0,5 \\
Marketing mix & 3,5 & 0,5 \\
Selling & 3,7 & 0,8 \\
Brand & 3,7 & 0,5 \\
Service & 3,6 & 0,6 \\
Process & 3,5 & 0,8 \\
Company Alignment Index & 3,6 & \\
\hline
\end{tabular}

Sumber : Data Sekunder diolah, 2020 (SPSS V 20). 
Terkait dengan hasil olah data diperoleh analisa dengan perbandingan CAI nilai lebih kecil dari CSI maka keberadaan Badan Usaha Milik Desa "X" di Marketing Oriented dan lebih disarankan untuk fokus ke lingkup tersebut.

\section{KESIMPULAN}

Melalui tahapan perhitungan diantara CAI > CSI, strategi Badan Usaha Milik Desa "X" dengan berpedoman pada The Strategic Marketing Plus 2000 conceptual Framework, key successful factors diantaranya :

1. Market Effective, dalam hal ini BUMDes mempunyai strategi yang efektif guna mencapai tujuannya. Perlu diperhatikan juga dalam optimalisasi penjualan pemasarannya. Jika produk dan jasa yang dimiliki BUMDes lebih fokus dan efektif sasarannya kepada konsumen di lingkup BUMDes tersebut. Dalam hal ini masyarakat desa setempat sebagai sasaran pasarnya.

2. Product Differentiation, adanya pembeda dalam produk atau jasa yang dimiliki BUMDes dengan lainnya. Hal ini diperlukan untuk memperoleh perhatian dari konsumen terkait dari manfaat, desain, harga, kualitas, pelayanan produk atau jasa BUMDes tersebut.

3. Balanced Promotion, diperhatikan bahwa dalam aktivitas promosi juga membutuhkan keseimbangan biaya. Kegiatan promosi produk dan jasa BUMDes yang tinggi memerlukan biaya yang tinggi. Sehingga dibutuhkan aktivitas promosi yang efektif namun juga tepat sasaran ke konsumen.

\section{DAFTAR PUSTAKA}

Cahyani, E. D., \& Ishak, Asmai. (2005). Audit Pemasaran Berdasarkan Strategic Marketing Plus 2000 CV. Morinda House Bogor. Sinergi: Kajian Bisnis dan Manajemen.

Cooper., Donald R, \& Pamela S., Schindler, (2006). Metode Riset Bisnis. Jakarta: PT Media Global Edukasi

Hendri., (2000). Analisis Audit Pemasaran Dengan Strategic Marketing Plus 2000: Studi Kasus Pada PT Khi Pipe Industries. Tesis. Pasca Sarjana Universitas Gadjah Mada. Yogyakarta

Kotler, P., Gregor, W., \& Rodgers, W. (1977). MARKETING AUDIT COMES OF AGE. Sloan Manage Rev. 
Kartajaya, Hermawan. (1995). Marketing Plus 3. Pustaka Sinar Harapan. Jakarta.

Kotler, P., \& Amstrong, G. (2012). Prinsip-Prinsip Pemasaran. Edisi 13. Jilid 1. Jakarta: Erlangga.

Kartajaya, Hermawan. (2000). Audit Pemasaran Berdasarkan Strategi Marketing Plus 2000. Yogyakarta: UGM

Shaw, T.N. (2008). A Discriminant Model for Assessment of Prospective Entrepreneurs for Financing and Success of Entrepreneurial Venture. Journal of Asia Entrepreneurship and Sustainability. 4(1): 69-82

Serrat, O., \& Serrat, O. (2017). Marketing in the Public Sector. In Knowledge Solutions. https://doi.org/10.1007/978-981-10-0983-9_16

Sugiyono. (2014). Metode Penelitian Kuantitatif Kualitatif dan R\&D. Bandung: Alfabeta.

Taghian, M., \& Shaw, R. N. (2008). The marketing audit and organizational performance: An empirical profiling. Journal of Marketing Theory and Practice. https://doi.org/10.2753/MTP1069-6679160406

Tjiptono., F, \& Chandra., G. (2012). Service, Quality Satisfaction. Jogjakarta: Andi Offset. 